Jurnal

Kardiologi Indonesia

J Kardiol Indones. 2015;36:242-4

ISSN $0126 / 3773$

\title{
Intermitten PR Interval Changes
}

\author{
Yoga Yuniadi
}

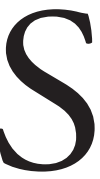

eorang anak perempuan usia 10 tahun dikonsulkan ke Divisi Aritmia dengan keluhan palpitasi berulang. Ekokardiografi menunjukkan anatomi dan fungsi jantung yang normal. Rekaman EKG diperlihatkan pada gambar 1 .

Takikardia QRS sempit dengan pola P-QRS-T yang menetap dapat merupakan suatu atrial atau sinus takikardia. Perhatikan bahwa gelombang $\mathrm{P}$ pada saat takikardia sama sekali berbeda dengan morfologi gelombang P saat irama sinus. Hal ini lebih menunjukkan suatu atrial takikardia daripada suatu irama sinus.

Atrial takikardia bisa merupakan suatu fokal atau makroreentri. Suatu atrial makroreentri atau atrial flutter umumnya mempunyai panjang siklus antara 200-150 mdet, sedangkan pasien ini mempunyai panjang siklus (interval PP) sekitar 380 mdet sehingga
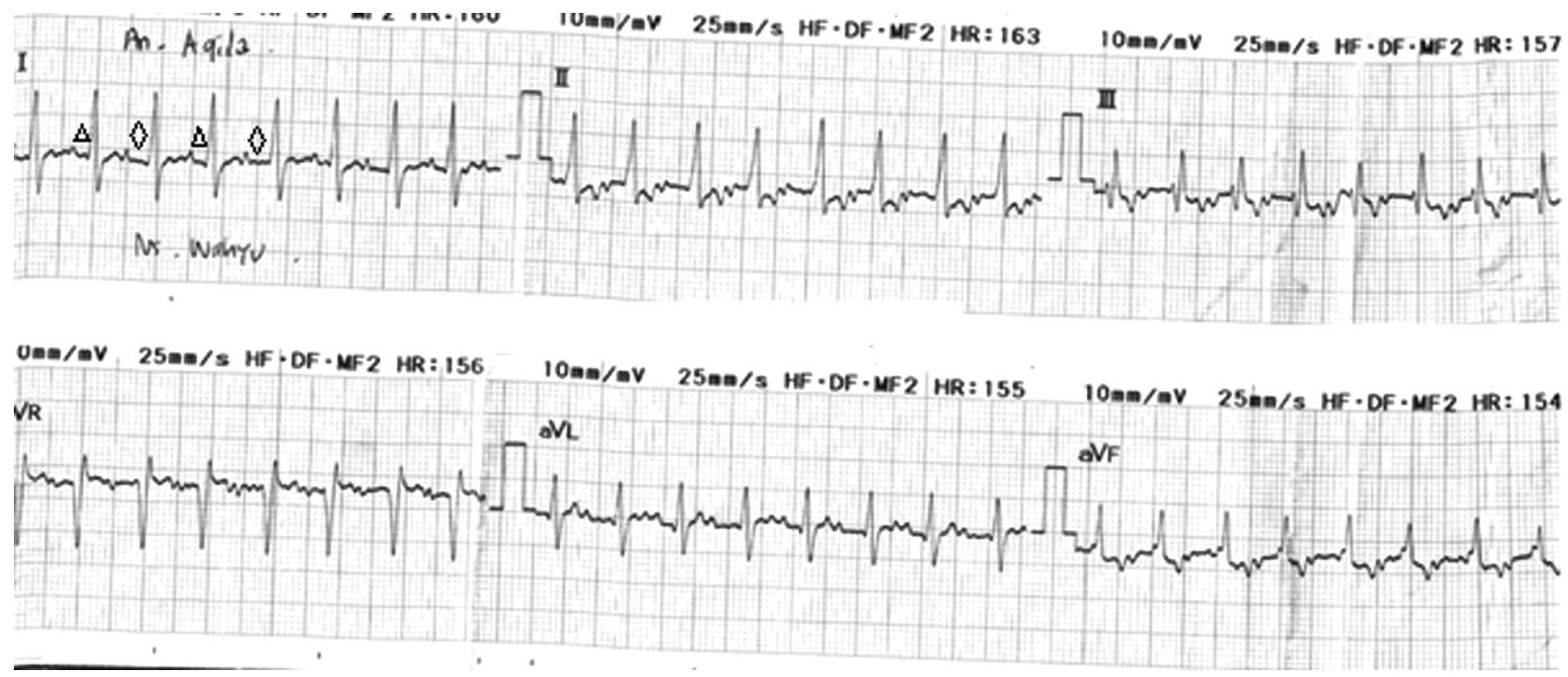

Gambar 1. Takikardia QRS sempit dengan variasi interval PR pendek $(\Delta)$ dan panjang $(\diamond)$ yang bergantian. Hal itu juga menyebabkan perbedaan kecil pada interval RR.

\section{Alamat Korespondensi}

Dr. dr. Yoga Yuniadi, SpJP. Divisi Aritmia, Departemen Kardiologi dan Kedokteran Vaskular, FKUI dan Pusat Jantung Nasional Harapan Kita, Jakarta. E-mail: yogay136@gmail.com suatu atrial takikardia yang fokal lebih memungkinkan. Di antara mekanisme atrial takikardia fokal dapat berupa otomatisasi, mikroreentri atau bahkan triggered activity. Perhatikan pola terminasi dan induksi 
takikardia seperti yang ditampilkan pada gambar 2 . Terlihat bahwa awitan dan akhiran takikardia bersifat mendadak yaitu seketika timbul dan seketika berhenti. Hal ini menunjukkan suatu mekanisme reentri.
Lalu kenapa terjadi perbedaan interval PR yang bergantian pada saat takikardia? Interval PE saat takikardia bergantian antara yang lebih pendek dan lebih panjang. Hal ini terjadi karena terdapat 2 jaras

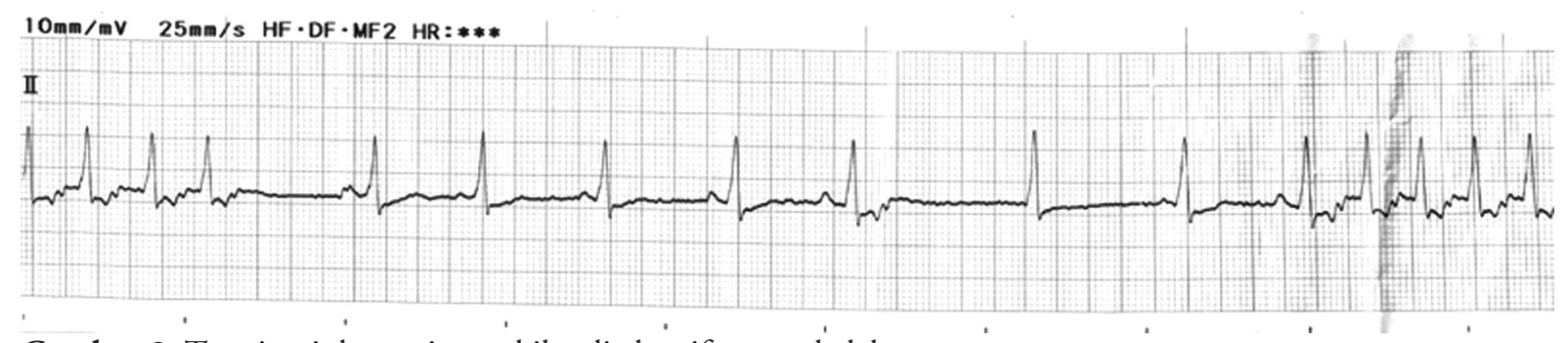

Gambar 2. Terminasi dan awitan takikardia bersifat mendadak.

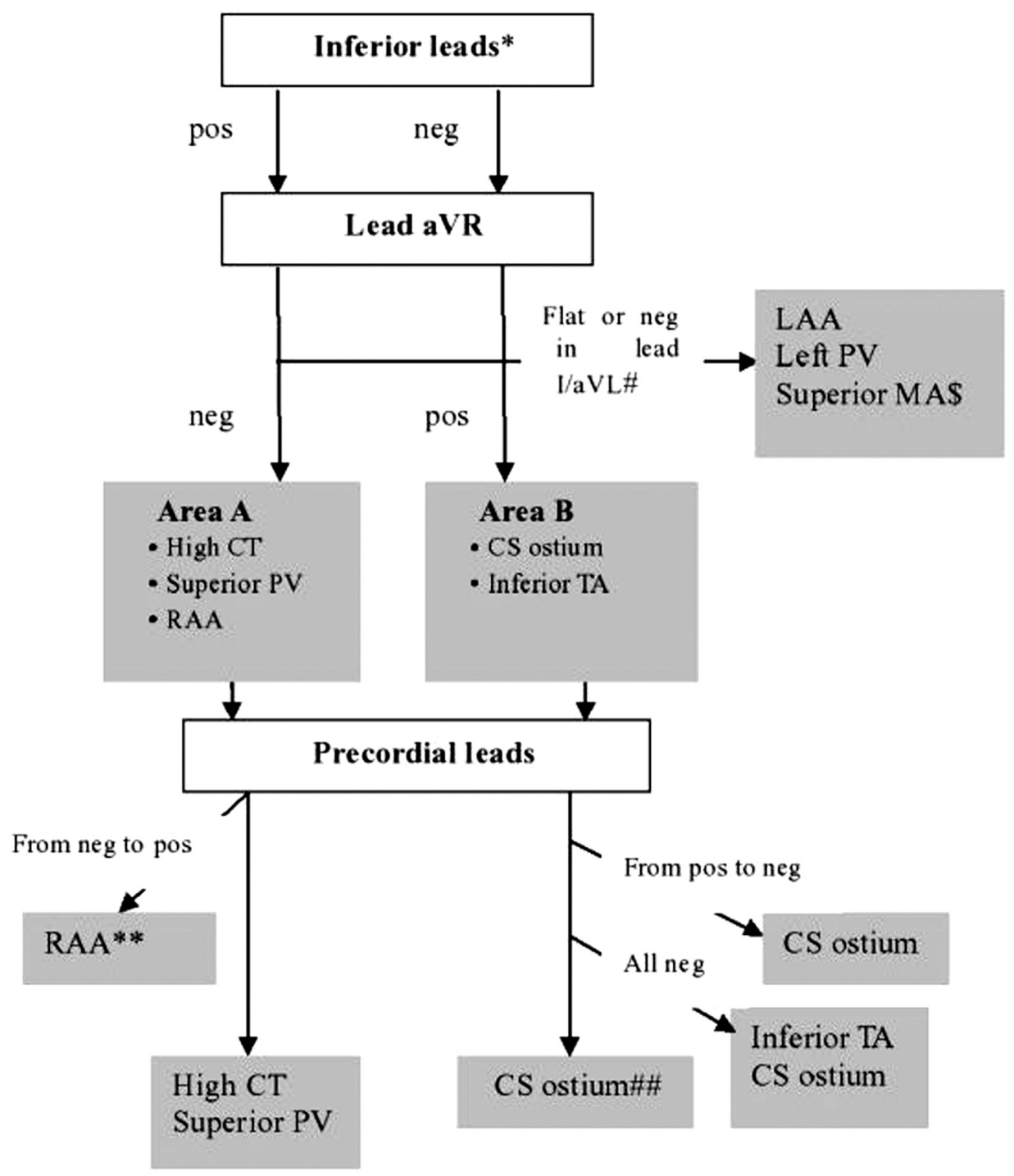

Gambar 3. Algoritme untuk prediksi asal atrial takikardia fokal berdasarkan morfologi gelombang P. 
konduksi melalui nodus AV yaitu jaras cepat dan jaras lambat. Jaras cepat dapat melalukan impuls dengan cepat tetapi masa pemulihan jaras untuk siap dilalui impuls kembali membutuhkan waktu yang lama. Sebaliknya jaras lambat melalukan impuls lebih lambat tetapi masa pemulihan lebih singkat. Ketika atrial takikardia terjadi pada pasien ini maka laju takikardia berada pada kisaran yang sedemikian rupa menyebabkan denyut berikutnya mendatangi nodus AV ketika jaras cepat masih belum pulih sehingga harus melalui jaras lambat. Hal ini menyebabkan interval PR bergantian antara pendek dan panjang. ${ }^{1}$

Dimana gerangan asal atrial takikardia tersebut? Perhatikan gelombang P di sadapan I dan aVL yang mempunyai polaritas positif, maka menunjukkan asal lokasi di atrium kanan. Kemudian perhatikan gelombang $\mathrm{P}$ di sadapan inferior yang dominan negatif dan juga negatif di aVR. Hal ini menunjukkan bahwa asal takikardia dapat berasal dari krista terminalis supeior hingga mid, vena pulmonalis superior atau apendiks atrium kanan. ${ }^{2}$ Dengan panduan ini maka jika dilakukan ablasi, pemetaan dapat difokuskan pada daerah tersebut. Ablasi pada apendiks atrium kanan berhasil mengeliminasi atrial takikardia pada pasien ini.

\section{Daftar Pustaka}

1. Evertz R, Merschon F, Berruezo A, Mont L. Dual ventricular response: another road to supraventricular tachycardia in dual atrioventricular nodal physiology. Rev Esp Cardiol (Engl Ed) 2013;66(2):145-6.

2. Qian ZY, Hou XF, Xu DJ, Yang B, Chen ML, Chen C, et al. An algorithm to predict the site of origin of focal atrial tachycardia. Pacing Clin Electrophysiol 2011;34(4):414-21. 